\title{
Infection of a Human Respiratory Epithelial Cell Line with Rhinovirus Induction of Cytokine Release and Modulation of Susceptibility to Infection by Cytokine Exposure
}

\author{
M. Cecilia Subauste, * David B. Jacoby, ${ }^{\ddagger}$ Stephen M. Richards, * and David Proud * \\ ${ }^{*}$ Department of Medicine, Division of Allergy and Clinical Immunology, and ${ }^{\ddagger}$ Department of Medicine, Division of Pulmonary and \\ Critical Care Medicine, The Johns Hopkins Asthma and Allergy Center, Baltimore, Maryland 21224-6801
}

\begin{abstract}
Rhinovirus infections cause over one third of all colds and are a contributing factor to exacerbations of asthma. To gain insights into the early biochemical events that occur in infected epithelial cells, we develop, for the first time, a model in which a pure respiratory epithelial cell population can be routinely infected by rhinovirus. Viral infection was confirmed by demonstrating that viral titers of supernatants and lysates from infected cell increased with time and by PCR. Infection by rhinovirus 14 was inhibited by homotypic antiserum and by antibodies to intercellular adhesion molecule-1 (ICAM-1), the receptor for this virus. Susceptibility of epithelial cells to infection by rhinovirus 14 (but not rhinovirus 2, an ICAM-1 independent strain) can be increased by preexposure of cells to TNF $\alpha$, whereas IFN $\gamma$ reduces susceptibility to infection by both rhinovirus strains. Rhinovirus infection per se does not markedly alter ICAM-1 expression on epithelial cells. Finally, we demonstrate that rhinovirus infection induced increased production of IL-8, IL-6, and GM-CSF from epithelial cells. Production of IL8 correlated with viral replication during the first $24 \mathrm{~h}$ after infection. This model should provide useful insights into the pathogenesis of rhinovirus infections. (J. Clin. Invest. 1995. 96:549-557.) Key words: common cold • asthma • airway inflammation - ICAM-1 - neutrophils.
\end{abstract}

\section{Introduction}

Rhinovirus infections are responsible for over $30 \%$ of all the common colds experienced each year (1). Moreover, it is becoming increasingly recognized that rhinovirus infection can be a precipitating or exacerbating factor of other diseases, including asthma (2-4), chronic bronchitis $(4,5)$, sinusitis $(6,7)$, and otitis media (8). Despite the high prevalence of rhinovirus

Address correspondence to David Proud, Ph.D., Johns Hopkins Asthma and Allergy Center, Unit Office 2, 5501 Hopkins Bayview Circle, Baltimore, MD 21224-6801. Phone: 410-550-2065; FAX: 410-550-2090.

Received for publication 2 July 1994 and accepted in revised form 1 March 1995.

1. Abbreviations used in this paper: HRV, human rhinovirus; ICAM1 , intercellular adhesion molecule-1; RSV, respiratory syncytial virus; TCID, tissue culture infective dose.

J. Clin. Invest.

(C) The American Society for Clinical Investigation, Inc.

0021-9738/95/07/0549/09 \$2.00

Volume 96, July 1995, 549-557 infections, the pathogenesis of the subsequent disease process is incompletely understood.

Several lines of evidence indicate that the respiratory epithelial cell is the primary site of rhinovirus infection in humans. Intercellular adhesion molecule-1 (ICAM-1), ${ }^{1}$ the receptor for the major group of rhinoviruses $(9,10)$, is known to be expressed by epithelial cells (11). Moreover, during colds, rhinovirus has been detected, in a limited number of shed epithelial cells, by indirect immunofluorescence (12), as well as in epithelial cells from biopsies of infected subjects by in situ hybridization (13). In contrast to infections with viruses such as influenza, rhinovirus infections result in no obvious changes in the morphology or integrity of the nasal epithelium (14), implying that symptoms are unlikely to be due to cytotoxic effects of the virus. It has been shown, however, that levels of inflammatory mediators, including kinins $(15,16)$ and IL-1 (17), are increased in nasal secretions of subjects with symptomatic colds, and it is known that symptomatic rhinovirus infections are associated with increased numbers of neutrophils both in the nasal mucosa (14) and in recovered nasal secretions $(15,18)$. Furthermore, the severity of nasopharyngeal symptoms in experimental colds also correlates with the numbers of lymphocytes in nasal secretions (18). Although the sequence of events leading from infection to the manifestation of symptoms, generation of mediators, and recruitment of cells remains unknown, it seems reasonable to hypothesize that this sequence of events must be initiated as a result of changes in the biochemistry of infected epithelial cells. If this is indeed the case, then delineation of such biochemical changes is of obvious importance for the development of improved therapeutic approaches to the management of rhinovirus infections and their complications. To perform such studies, however, it is clearly critical to be able to routinely infect respiratory epithelial cells with rhinovirus in a setting independent of other cell types that are normally present in the airway mucosa.

We now report a method by which a pure human respiratory epithelial cell line can be routinely infected with rhinovirus and present initial studies on the regulation of susceptibility to viral infection by preexposure to cytokines. Moreover, we demonstrate that infection of these cells with rhinovirus leads to increased production of proinflammatory cytokines that could play a role in the pathogenesis of symptomatic infections.

\section{Methods}

Viruses, viral antisera, cell lines, and media components. Human rhinovirus types 14 (HRV-14) and 2 (HRV-2), HeLa cells, and guinea pig polyclonal antisera to HRV-14 and HRV-2 were purchased from American Type Culture Collection (Rockville, MD). The BEAS-2B cell line was kindly provided by Dr. Curtis Harris (National Cancer Institute, Bethesda, MD). This cell line was derived from normal human bronchial epithelial cells by transfection with an adenovirus 12-SV40 
hybrid virus (19). Reagents for culture media were obtained as follows: Ham's F-12 medium, and penicillin/streptomycin/fungizone (GIBCO Laboratories, Grand Island, NY); insulin, hydrocortisone, EGF, endothelial cell growth supplement, and triiodothyronine (Collaborative Research, Bedford, MA); cholera toxin (Sigma Chemical Co., St. Louis, MO); and DME supplemented with $10 \%$ FBS (Biofluids, Rockville, MD).

Epithelial cell culture. The BEAS-2B cells used in our studies were cultured as previously described (20) and were used between passages 35 and 50. Cells were plated on 6-well plates (Costar, Cambridge, MA) at a density of $2.5 \times 10^{4}$ cells $/ \mathrm{cm}^{2}$ in a serum-free medium consisting of Ham's F-12 nutrient medium that contained penicillin, streptomycin, and fungizone $(100 \mathrm{U} / \mathrm{ml}, 100 \mathrm{U} / \mathrm{ml}$, and $250 \mathrm{ng} / \mathrm{ml}$, respectively), insulin $(5 \mu \mathrm{g} / \mathrm{ml})$, hydrocortisone $\left(10^{-7} \mathrm{M}\right)$, EGF $(12.5 \mathrm{ng} / \mathrm{ml})$, endothelial cell growth supplement $(3.75 \mu \mathrm{g} / \mathrm{ml})$, triiodothyronine $\left(3 \times 10^{-9}\right.$ $\mathrm{M})$, and cholera toxin $(10 \mathrm{ng} / \mathrm{ml})$. This medium is referred to as F12/ $6 \mathrm{X}$. The cells were incubated at $37^{\circ} \mathrm{C}$ in humidified air that contained $5 \% \mathrm{CO}_{2}$.

Viral stocks. A stock solution of HRV-14 was generated by infecting monolayer cultures of HeLa cells. Cultures were grown in DME/FBS for several days until cytopathic effects were obvious, after which the cultures were frozen at $-70^{\circ} \mathrm{C}$, thawed, and sonicated. The virus-containing fluid so obtained was frozen in aliquots at $-70^{\circ} \mathrm{C}$. The content of viral stock solutions was determined using the HeLa cell assay described below. Because of the limited number of studies performed with HRV2 , stocks of this virus were used directly as obtained from the supplier.

Detection and titration of viruses. Rhinoviruses were detected by exposing confluent monolayers of HeLa cells in 96-well plates to serial 10-fold dilutions of virus-containing medium or lysates in Ham's F-12/ $10 \%$ FBS. Plates were then incubated at $34^{\circ} \mathrm{C}$ for $5 \mathrm{~d}$ after which the medium was removed, and cells were washed with $100 \mu \mathrm{l}$ of PBS and fixed by adding $50 \mu \mathrm{l}$ of methanol per well for $1 \mathrm{~min}$. The methanol was then replaced with $100 \mu \mathrm{l}$ of $0.1 \%$ crystal violet in distilled water for $20 \mathrm{~min}$. Plates were washed, and absorbance at $570 \mathrm{nM}$ was measured using a plate reader. The amount of specimen required to infect $50 \%$ of monolayers $\left(\mathrm{TCID}_{50}\right)$ was determined. Specificity was confirmed by showing that preincubation of viral medium with a serotypespecific rhinovirus antibody, but not with an irrelevant antibody, for 30 min blocked the cytopathic effect on HeLa cells.

Viral infection of BEAS- $2 B$ cells. Medium was removed from subconfluent monolayers of BEAS-2B cells and was replaced with $2 \mathrm{ml}$ HBSS (Biofluids). Rhinovirus was added at appropriate concentrations. For routine infections, a concentration of $10^{2.5} \mathrm{TCID}_{50} / \mathrm{ml}$ was used. After a 1-h incubation at $34^{\circ} \mathrm{C}$, the viral solution was removed and the cells were washed once with $2 \mathrm{ml}$ of fresh HBSS. Cells were then fed with $\mathrm{F} 12 / 6 \mathrm{X}$ and incubated at $34^{\circ} \mathrm{C}$. Supernatants were removed at various times after infection and stored at $-70^{\circ} \mathrm{C}$ for determination of viral content. Viral titers of the material used for infection and of the supernatants removed at the end of the infection period were also determined to estimate the maximal amount of viral uptake that had occurred during the exposure period. As an additional control for nonspecific adherence of virus, the content of inocula after a 1-h incubation in empty wells was also assessed. Finally, cell-associated viral content was also analyzed using sonicated BEAS-2B cells.

Effect of type-specific antisera on HRV-14 infection. HRV-14 (10 $10^{2.5}$ $\mathrm{TCID}_{50} / \mathrm{ml}$ ) was incubated for 30 min with a 1:10 dilution of antiserum to HRV-14. The virus was then incubated with BEAS-2B cell monolayers at $34^{\circ} \mathrm{C}$ for $15 \mathrm{~min}$ in $95 \%$ air-5\% $\mathrm{CO}_{2}$ before washing the monolayer and culturing in F12/6X. BEAS-2B cell monolayers were also exposed for the same time period to HRV-14 that had been incubated with a 1:10 dilution of antiserum to HRV-2 or with no antibody. The viral content of the supernatant culture medium $24 \mathrm{~h}$ after infection was determined as described above.

Effect of antibodies to ICAM-1 on HRV-14 infection. Subconfluent epithelial cells were incubated for $60 \mathrm{~min}$ at $37^{\circ} \mathrm{C}$ in $95 \%$ air-5\% $\mathrm{CO}_{2}$ with medium alone or with medium containing either of two mouse monoclonal anti-human antibodies to ICAM-1:84H10 (AMAC Company, Westbrook, MA) or RR1 (a gift from Dr. R. Rothlein, Boehringer
Ingelheim, Ridgefield, CT). Both of these antibodies recognize the ICAM-1 functional domain. As an additional control, monolayers were also incubated with medium containing a class-matched monoclonal antibody to HLA-1. After washing off excess antibodies, the monolayers were exposed to HRV-14 $\left(10^{2.5} \mathrm{TCID}_{50} / \mathrm{ml}\right)$ for $15 \mathrm{~min}$ before rinsing and adding fresh F12/6X medium. The viral content of this medium was then assessed after $24 \mathrm{~h}$.

Detection of rhinovirus $m R N A$ by reverse transcription-PCR. Confluent monolayers of BEAS-2B cells, in 6-well plates, were exposed to medium alone or to medium containing HRV-14 $\left(10^{3.5} \mathrm{TCID}_{50} / \mathrm{ml}\right)$ for $15 \mathrm{~min}$. Monolayers were then washed and placed in F12/6X. From the cells exposed to virus, RNA was extracted at 0,1 , and $24 \mathrm{~h}$ after the 15-min exposure period, while for cells exposed to medium alone, RNA was extracted only at $24 \mathrm{~h}$ after exposure. For each sample, RNA was extracted using the GlassMAX RNA microisolation system (GIBCO/BRL, Gaithersburg, MD). In brief, $300 \mu \mathrm{l}$ of ice-cold guanidine isothiocyanate containing 2-mercaptoethanol was added to each well and the cells were lifted by scraping. After transfer to a microcentrifuge tube, each sample was mixed thoroughly by vortexing and the RNA was precipitated with ethanol. After centrifugation, the RNA was resuspended in an acidic sodium iodide solution and passed over a spin cartridge containing a silica-based membrane. After washing, the RNA was subsequently eluted into a sterile microcentrifuge tube using $50 \mu \mathrm{l}$ of diethylpyrocarbonate-treated water that had been prewarmed to $65^{\circ} \mathrm{C}$.

After drying, the RNA was resuspended in $3.5 \mu$ l of diethylpyrocarbonate-treated water and mixed with $0.5 \mu \mathrm{l}$ each of $10 \times$ DNase I reaction buffer and DNase I to degrade any traces of genomic DNA. The DNase I was subsequently inactivated by addition of $0.5 \mu \mathrm{l}$ of $20 \mathrm{mM}$ EDTA and heating for $10 \mathrm{~min}$ at $65^{\circ} \mathrm{C}$. Reverse transcription reactions were carried out on aliquots of isolated RNA for $60 \mathrm{~min}$ at $37^{\circ} \mathrm{C}$ in a final volume of $20 \mu \mathrm{l}$ using Superscript Reverse Transcriptase (GIBCO/ BRL) in the presence of DTT, human placental RNase inhibitor, $1 \mu \mathrm{l}$ each of $10 \mathrm{mM}$ solutions of nucleoside triphosphates (dATP, dTTP, dCTP, and dGTP), and $200 \mathrm{ng}$ of the downstream oligonucleotide primer to be used for the subsequent PCR. After reverse transcription, PCR was performed using two primers designated OL26 (upstream, 5'GCACTTCTGTTTCCCC3') and OL27 (downstream, 5'CGGACACCCAAAGTAG3') that are directed to a highly conserved $5^{\prime}$ noncoding region of the viral genome (21). These PCR primers were synthesized by the Johns Hopkins University Genetics Resources Core. PCR reactions were carried out in a final volume of $50 \mu 1$ in a PCR machine (Perkin-Elmer Cetus, Norwalk, CT) programmed as follows: one denaturing cycle at $94^{\circ} \mathrm{C}$ for $2 \mathrm{~min}, 30$ reaction cycles at $94^{\circ} \mathrm{C}$ for $1 \mathrm{~min}$, $55^{\circ} \mathrm{C}$ for $2 \mathrm{~min}$, and $72^{\circ} \mathrm{C}$ for $4 \mathrm{~min}$, followed by a final extension cycle at $72^{\circ} \mathrm{C}$ for $5 \mathrm{~min}$. A positive reaction is indicated by a product at 380 bp. The identity of the PCR product was confirmed by Southern blotting using a labeled internal oligonucleotide probe JWA-1 (5'GCATTCAGGGGCCGGAG3') as described previously (21).

Effects of exposure to cytokines on susceptibility to infection with rhinovirus. Because HRV-14 uses ICAM-1 as its cellular receptor, we examined the effects of cytokines that are known to increase the expression of ICAM-1 on BEAS-2B cells on the susceptibility of the cells to infection HRV-14. It has been shown that TNF $\alpha$ and IFN $\gamma$ are each capable of increasing the expression of ICAM-1 on BEAS-2B cells and that the effects of the two cytokines are additive $(22,23)$. Monolayers of BEAS-2B cells were incubated, therefore, for $24 \mathrm{~h}$ with either TNF $\alpha$ ( $10 \mathrm{U} / \mathrm{ml}$, Genzyme, Cambridge, MA), IFN $\gamma(30 \mathrm{U} / \mathrm{ml}$, Biosource International, Camarillo, CA), or to both TNF $\alpha(10 \mathrm{U} / \mathrm{ml})$ and IFN $\gamma$ $(30 \mathrm{U} / \mathrm{ml})$. These concentrations were shown earlier to be optimal for inducing ICAM-1 expression on BEAS-2B cells (23). We also tested the effects of IFN $\alpha$ ( $30 \mathrm{U} / \mathrm{ml}$, Biosource International) and IL-1 ( $1 \mathrm{ng} /$ $\mathrm{ml}$, UBI, Lake Placid, NY), which do not increase ICAM-1 expression on epithelial cells. After removal of cytokines, cells were exposed to serial 10 -fold dilutions of virus for $1 \mathrm{~h}$ at $34^{\circ} \mathrm{C}$. After viral infection, cells were incubated in F12/6X. Medium was replaced daily. The presence of virus in medium removed after $72 \mathrm{~h}$ was determined to assess whether infection occurred at each dose of virus used. For all of these experi- 
ments, this index of susceptibility to infection, defined as the minimum dose of virus that could induce infection, was compared with the susceptibility of control BEAS-2B cells that were not preincubated with cytokines. To further study the role of ICAM-1 in observed effects, additional paired experiments were performed in which the effects of cytokines on the susceptibility to HRV-14 were compared with effects on susceptibility with HRV-2, which does not use ICAM-1 as its receptor.

Effects of HRV-14 infection on ICAM-1 expression. Confluent monolayers of BEAS-2B cells were exposed to HRV-14 $\left(10^{3.5} \mathrm{TCID}_{50} / \mathrm{ml}\right)$ for $1 \mathrm{~h}$. After $1,4,12$, and $24 \mathrm{~h}$, cells were removed from the plates by repeated pipetting in $\mathrm{Ca} / \mathrm{Mg}$-free HBSS that contained 6 mM EGTA (20). For each analysis, $1.5 \times 10^{5}$ cells were incubated for $30 \mathrm{~min}$ at $4^{\circ} \mathrm{C}$ in $20 \mu \mathrm{l} \mathrm{PBS} / 0.2 \%$ BSA $/ 0.4 \%$ human IgG (to block Fc receptors) that contained either $84 \mathrm{H} 10$ or My-13 (Zymed, South San Francisco, CA), a monoclonal antibody that recognizes a nonfunctional domain of ICAM-1. The cells were washed, resuspended in saturating amounts of FITC-conjugated goat $\mathrm{F}\left(\mathrm{ab}^{\prime}\right)$ anti-mouse IgG for $30 \mathrm{~min}$, and then washed again. Fluorescence was measured using a flow cytometer (EPICS Profile, Coulter Electronics Inc., Hialeah, FL) and was expressed as mean fluorescence intensity (24). The percentage of cells staining positively with each monoclonal antibody was calculated by comparison with background staining using an irrelevant class-matched mouse monoclonal as the primary antibody (Coulter).

Neutrophil adhesion to BEAS-2B cell monolayers. Human neutrophils of $>95 \%$ purity were obtained from peripheral blood of healthy volunteers by density gradient centrifugation and hypotonic lysis of erythrocytes using previously described methods (25). Viability of neutrophil preparations always exceeded $95 \%$, as assessed by exclusion of erythrocin B dye. For radiolabeling, neutrophils were suspended at a concentration of $2.5 \times 10^{6}$ cells $/ \mathrm{ml}$ and were incubated with ${ }^{51} \mathrm{Cr}$ for $30 \mathrm{~min}$ at $37^{\circ} \mathrm{C}$, as described previously (25). Neutrophils were washed and $2.5 \times 10^{5}$ cells were added to each well of 24-well plates containing confluent BEAS-2B monolayers $24 \mathrm{~h}$ after the monolayers had been exposed to virus or to medium. Viral infection of exposed monolayers was confirmed by monitoring the cytopathic effects of cell supernatants on HeLa cells as described above. Neutrophils, either nonactivated or after activation with $1 \mu \mathrm{M}$ FMLP, were incubated with BEAS-2B cells for $10 \mathrm{~min}$ at $37^{\circ} \mathrm{C}$ before nonadherent cells were removed by aspiration and rinsing. Adherent cells were then lysed with $1 \mathrm{M}$ ammonium hydroxide. Neutrophil binding was quantified as the amount of radioactivity in each lysate, as detected by a gamma counter. Results were expressed as the percentage of the total counts added to each well that bound to the monolayer.

Effects of HRV-14 infection on production of cytokines. In initial experiments, monolayers of BEAS-2B cells were infected with HRV$14\left(10^{2.5} \mathrm{TCID}_{50} / \mathrm{ml}\right)$, and supernatants recovered $24 \mathrm{~h}$ later were analyzed for the presence of IL-8, IL-6, and GM-CSF. Based on the data obtained, supernatants recovered at differing times after viral infection during the experiments that were used to monitor viral titers were used to examine the time course of production of $\mathrm{IL}-8$, the cytokine released in the greatest amounts. Levels of IL-6 and GM-CSF in cell supernatants were assayed using commercial kits (R\&D Systems, Minneapolis, MN). Levels of IL-8 were measured using an ELISA sensitive to $30 \mathrm{pg} / \mathrm{ml}$ of IL-8. Plates are coated with $100 \mu \mathrm{l}$ of a 1:1,200 dilution of a purified IgG fraction of a polyclonal rabbit anti-human IL-8 antibody. After blocking nonspecific binding sites with $1 \%$ sheep serum in PBS, a 100$\mu l$ volume of standards, or appropriately diluted samples, are incubated for $90 \mathrm{~min}$ at $37^{\circ} \mathrm{C}$. Wells are washed and then incubated for $90 \mathrm{~min}$ at $37^{\circ} \mathrm{C}$ with $100 \mu$ l of the same anti-human IL-8 that has been biotinylated. Positive samples are detected by incubation for $30 \mathrm{~min}$ with streptavidin-peroxidase and subsequent addition of $100 \mu \mathrm{l}$ of $1 \mathrm{mM} \mathrm{2,2'-}$ azino-di-[ 3 ethylbenzthiazoline sulfonic acid] as a substrate, and the absorbance is read at $410 \mathrm{~nm}$ on a plate reader. The assay shows no crossreactivity with RANTES, MIP-1, GRO, or a series of other members of the chemokine family. Structurally unrelated cytokines, including IL-1, IL-2, IL-3, IL-4, IL-5, IL-6, TNF $\alpha$, and GM-CSF also show no crossreactivity. Analysis of several epithelial cell supernatants in this
Table I. Effects of Rhinovirus 14 Infection on Expression of ICAM-1 on BEAS-2B Cells

\begin{tabular}{ccc}
\hline \multirow{2}{*}{$\begin{array}{c}\text { Time after } \\
\text { infection }(h)\end{array}$} & \multicolumn{2}{c}{ ICAM-1 expression (fold of control noninfected cells) } \\
\cline { 2 - 3 } & Antibody $84 \mathrm{H} 10^{*}$ & Antibody My13 \\
\hline 0 & $1.17 \pm 0.29$ & $0.94 \pm 0.07$ \\
4 & $1.05 \pm 0.25$ & $1.10 \pm 0.09$ \\
12 & $1.3 \pm 0.37$ & $1.17 \pm 0.07$ \\
24 & $1.5 \pm 0.26$ & $1.76 \pm 0.33$ \\
\hline
\end{tabular}

Values are means $\pm \mathrm{SD} ; n=3 .{ }^{*}$ Directed to functional binding site of ICAM-1. ${ }^{\ddagger}$ Directed to nonfunctional component of ICAM-1.

assay provided results that were in excellent agreement with those obtained in a commercial assay ( $\mathrm{R} \& \mathrm{D}$ Corp.).

To confirm that cytokine production was indeed due to the effects of rhinovirus infection and not to a contaminant present in the viral stock, two different types of experiments were performed to prevent infection with HRV-14. First, as described above, epithelial cells were preincubated using a monoclonal antibody (84H10) to ICAM-1 or a class-matched IgG $_{1}$ control monoclonal at an identical concentration, and the effects of epithelial cell IL-8 production examined. Second, the ability of ultraviolet (UV)-inactivated virus to induce cytokine production was also examined. UV inactivation was performed as described previously (26).

Statistical analysis. Demonstration of significant increases in viral titers was performed using a one-way ANOVA. The effects of cytokines on the dose of virus necessary to cause infections were compared using Student's $t$ tests. Analysis of the effects of viral infection and time on the expression of ICAM-1 on BEAS-2B cells was performed using a two-way repeated measures ANOVA. A similar analysis was used to examine the effects of viral infection and time on IL-8 production. Subsequent post-hoc analysis was performed using paired Student's $t$ tests. The effects of anti-ICAM-1 and of UV inactivation on virally induced cytokine production were compared by paired $t$ tests after normalizing data from each experiment in terms of increases induced by virus. For all analyses, values of $P<0.05$ were assumed to be significant.

\section{Results}

$H R V-14$ infection of BEAS-2B cells. Exposing subconfluent BEAS-2B cell monolayers to HRV-14 $\left(10^{2.5} \mathrm{TCID}_{50} / \mathrm{ml}\right)$ consistently led to infection. In each of four experiments used to monitor viral titers, the supernatant removed after the 1-h infection period still contained $10^{2.5} \mathrm{TCID}_{50} / \mathrm{ml}$ of virus when assessed in the HeLa cytotoxicity assay, implying that only a small amount of virus was taken up by the cells. Subsequent collection of culture medium at differing times after viral exposure revealed no detectable virus at 1 and $4 \mathrm{~h}$ after infection. Virus was detected in the culture medium $8 \mathrm{~h}$ after infection, and the viral content progressively increased between 8 and 24 $\mathrm{h}$ after infection (Fig. 1, left). Evidence of continuous viral production was obtained by demonstrating that the viral titers of supernatants collected during the second and third 24-h periods after infection each contained similar levels of virus to those detected at $24 \mathrm{~h}$ after infection (Fig. 1, right). Analysis of the levels of cell-associated virus (the virus detectable in sonicates of the BEAS-2B cells) followed a similar time course to that observed in the medium (Fig. 2). Again, these data suggested 


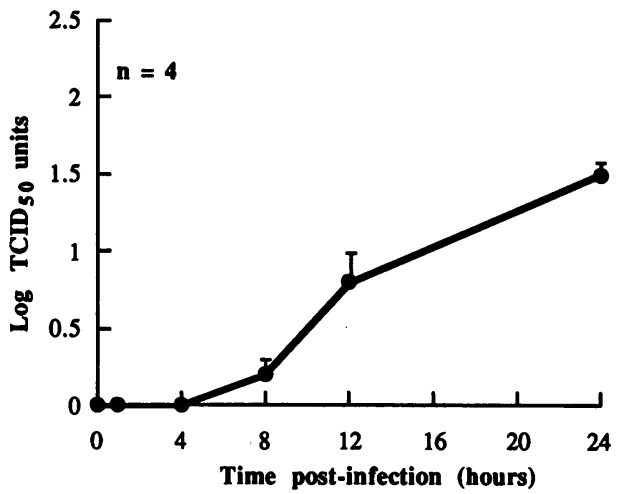

that very little virus is initially taken up by the cells, because there was no detectable virus at 0 or $4 \mathrm{~h}$ after the infection period. By $12 \mathrm{~h}$, however, virus was clearly detectable and titer levels continued to increase at $24 \mathrm{~h}$ (Fig. 2, left). Viral titers then stayed reasonably constant when cells were lysed at 48 and $72 \mathrm{~h}$ postinfection (Fig. 2, right), despite continuing release into the supernatants. In both cell supernatants and lysates, viral titer levels increased significantly with time $(P<0.05$ in each case by ANOVA). BEAS-2B cell viability, as assessed by exclusion of erythrocin B, was consistently $>95 \%$ in HRV-14infected cultures. Rhinovirus infection also had no effect on cell growth. In nine experiments, using cells at differing levels of confluency, cell counts $24 \mathrm{~h}$ after infection were not different (noninfected, $6.6 \pm 1.1 \times 10^{5}$; infected, $7.0 \pm 1.3 \times 10^{5} ; P=0.5$ by paired $t$ test).

Detection of viral RNA by PCR. Further evidence of rhinovirus infection of BEAS-2B cells, and of viral replication, was provided by PCR analysis (Fig. 3). In each of three experiments, RNA extracted from control uninfected cells did not produce any detectable PCR product at $380 \mathrm{bp}$ (lane 2). Similarly, no product was detected using RNA extracted from cells immediately after the 15 -min exposure period to virus (lane 3 ), again implying that very little virus is initially taken up by the cells. A faint product was observable in RNA extracted from cells $1 \mathrm{~h}$ after the infection period (lane 4 ), while a clear product band was observed using RNA extracted from cells $24 \mathrm{~h}$ after the infection period (lane 5).

Effect of type-specific viral antisera and anti-ICAM-1 on $H R V-14$ infection. In four experiments, HRV-14 infection of BEAS-2B cells led to measurable viral titers in supernatants collected $24 \mathrm{~h}$ after viral exposure $\left(1.4 \pm 0.1 \log \mathrm{TCID}_{50}\right.$ units; mean \pm SEM). Infection could be completely blocked in all of these experiments by preincubation of the virus with polyclonal antiserum to HRV-14. In contrast, HRV-14 infection could not be blocked by polyclonal antiserum to HRV-2, as medium collected $24 \mathrm{~h}$ after exposure contained levels of virus similar to those found in BEAS-2B cells exposed only to HRV-14 in the absence of antibody $\left(1.25 \pm 0.1 \log \mathrm{TCID}_{50}\right.$ units $)$. Preincubation of BEAS-2B cells with a monoclonal antibody $(84 \mathrm{H} 10)$ to ICAM-1 also completely blocked the subsequent infection of these cells with HRV-14. HRV-14 infection could also be totally inhibited using a second monoclonal antibody (RR1) to ICAM-1.

Effects of cytokine pretreatment on susceptibility to $H R V$ infection. Pretreatment of BEAS-2B cells for $24 \mathrm{~h}$ with TNF $\alpha$ $(10 \mathrm{U} / \mathrm{ml})$ increased the susceptibility of BEAS-2B cells to HRV-14 infection, decreasing by 10 -fold the minimum dose of virus necessary to cause infection (Fig. 4). In contrast, both IFN $\gamma$ and IFN $\alpha$ reduced the susceptibility to infection, increasing the minimum dose of HRV-14 necessary to cause infection by 10 -fold. Pretreatment with IL-1 did not affect the susceptibility to infection. Interestingly, when cells were preincubated with a combination of TNF $\alpha$ and IFN $\gamma$, the effects of IFN $\gamma$ predominated in that susceptibility to infection was decreased (Fig. 4).

To evaluate the role of alterations of ICAM-1 expression in the effects of TNF $\alpha$ and IFN $\gamma$ on susceptibility of BEAS-2B cells to infection by HRV-14, additional paired experiments were performed on three different passages of BEAS-2B cells to compare the effects of these cytokines on susceptibility to infection with HRV-14 and HRV-2. In each experiment, HRV-
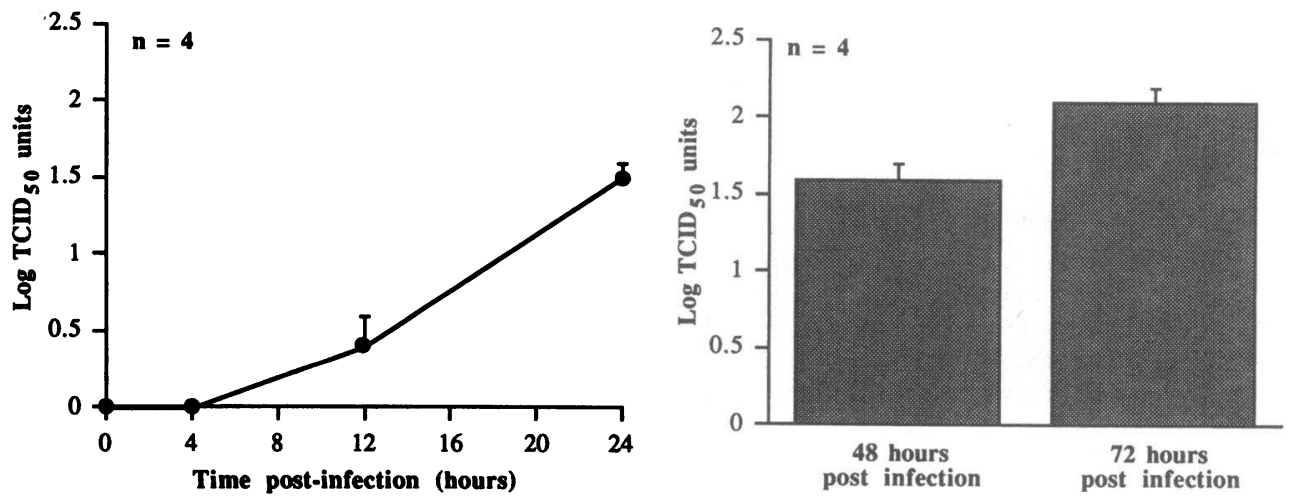

Figure 2. Titers of rhinovirus in BEAS-2B cell lysates recovered at differing times after infection. (Left) Titers at sequential times during the first $24 \mathrm{~h}$ after infection. (Right) Viral titers in lysates collected at 48 and $72 \mathrm{~h}$ after infection. For the latter time points the medium above cells was replaced every $24 \mathrm{~h}$. Data are expressed as means $\pm \operatorname{SEM}(n=4)$. 


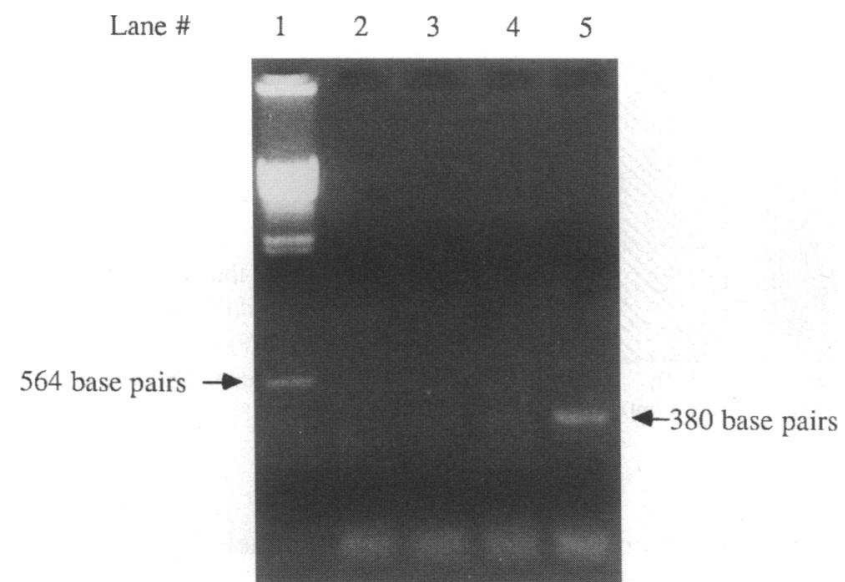

Figure 3. Detection of replication of rhinovirus RNA by reverse transcription-PCR. A positive signal is demonstrated by a band at $380 \mathrm{bp}$. Lane 1, גDNA/Hind III fragment molecular weight markers; lane 2, RNA extracted from noninfected cells; lanes 3-5, RNA from cells at 0,1 , and $24 \mathrm{~h}$ after infection, respectively. Data are representative of three different experiments.

2 was also capable of infecting BEAS-2B cells. The dose of virus necessary to cause infection was higher than that needed for HRV-14, but this was also the case for infecting HeLa cells (not shown). Preincubation with IFN $\gamma$ increased by 10 -fold the minimum dose of both HRV-14 and HRV-2 that were necessary to cause infection. In contrast, although preincubation with TNF $\alpha$ again increased the susceptibility to infection by HRV14 , this cytokine had no effect on the minimum dose of HRV2 that was necessary to cause infection (Fig. 5).

Effects of HRV-14 infection on expression of ICAM-1. Flow cytometry analysis of ICAM-1 expression at differing times after incubation of cells with rhinovirus gave similar results with each of the two monoclonal antibodies used (Table I). Even in control noninfected cells, all cells expressed ICAM-1. A small increase in ICAM-1 was seen $24 \mathrm{~h}$ after infection in each of three experiments, but there were no statistically significant differences when analyzed by ANOVA. Moreover, this modest increase in ICAM-1 expression was not associated with an increased capacity for neutrophil adhesion. In three experiments, adhesion of nonactivated neutrophils to infected epithelial cells was $4.1 \pm 0.3 \%$, whereas adhesion to noninfected monolayers was $4.6 \pm 0.5 \%$. Similarly, adherence of FMLP-activated neutrophils was $21.5 \pm 0.5 \%$ to infected monolayers and $21.0 \pm 2 \%$ to noninfected epithelial cells.

Effect of HRV-14 infection on cytokine production. An initial analysis of supernatants collected from infected and control cells at $24 \mathrm{~h}$ after infection showed that rhinovirus infection increases cytokine secretion (Fig. 6). Because viral infection did not alter cell numbers (see above), all cytokine values are reported in picograms per milliliter of supernatant. Secretion of $\mathrm{IL}-8, \mathrm{IL}-6$, and GM-CSF were all increased in response to rhinovirus infection, although in terms of absolute levels, IL-8 production $(2,100 \pm 200 \mathrm{pg} / \mathrm{ml})$ predominated. Quite high levels of IL-6 $(1,070 \pm 202 \mathrm{pg} / \mathrm{ml})$ were also produced, whereas GMCSF levels $(30 \pm 1 \mathrm{pg} / \mathrm{ml})$ were markedly lower. Because IL-8 was the predominant cytokine produced, further studies were performed to relate secretion of this cytokine to viral titer levels.

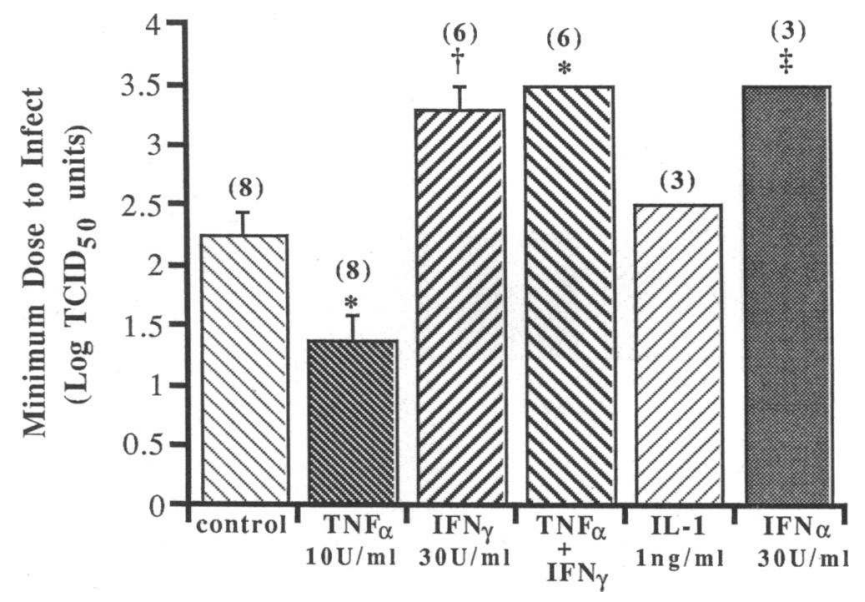

Figure 4. Effects of 24-h preexposure of BEAS-2B cells to cytokines on susceptibility to infection by HRV-14. Data are expressed as means\pm SEM. Numbers in parentheses indicate the number of experiments in which each cytokine was tested. ${ }^{*} P<0.001$ vs. control; ${ }^{\dagger} P<0.01$ vs. control; ${ }^{\ddagger} P<0.05$ vs. control.

Aliquots of supernatants from the same experiments used to assay the viral titers shown in Fig. 1 were assayed for IL-8 (Fig. 7). During the first $24 \mathrm{~h}$ after infection, IL-8 production increased in a manner that paralleled viral titers. Statistical analysis by ANOVA demonstrated that the curves for cytokine production from infected and noninfected cells were significantly different $(P<0.05)$, with interactive effects of both treatment and time. Maximal IL-8 production was seen $24 \mathrm{~h}$ after infection when $1,075 \pm 250 \mathrm{pg} / \mathrm{ml}$ was detected in the culture medium from infected cells compared with $410 \pm 240 \mathrm{pg} / \mathrm{ml}$ in the culture medium from control cells $(P<0.005)$. By repeated-measure ANOVA, there were no significant differences with respect to time or treatment between each of the 24-h collection periods. Thus, by the second and third 24-h collection periods after infection, when IL-8 production from infected cells was reduced to $525 \pm 130$ and $730 \pm 175 \mathrm{pg} / \mathrm{ml}$, respectively, these values were no longer different from those from noninfected cells (Fig. 7).

To confirm that cytokine production was induced by rhinovirus and not by a contaminant in the viral stocks, the effects of preincubation of epithelial cells with mouse monoclonal antibody to human ICAM-1 (84H10), or an irrelevant mouse classmatched monoclonal $\mathrm{IgG}_{1}$ control, on cytokine production 24 $h$ after viral exposure were examined. Infection of cells with HRV-14 again resulted in a stimulation of IL-8 production, almost tripling the levels seen in supernatants from noninfected cells (Fig. 8). Incubation of cells with antibody to ICAM-1 again completely blocked viral infection, as assessed by the absence of detectable viral titers in the supernatants recovered $24 \mathrm{~h}$ after viral exposure (not shown). This treatment also significantly $(P<0.02)$ inhibited the virally induced increases in IL-8 production. By contrast, the irrelevant $\mathrm{IgG}_{1}$ monoclonal had no effect on IL-8 production (Fig. 8). As an additional control, the effects of UV inactivation of rhinovirus was also examined in three experiments. Spontaneous production from noninfected cells at $24 \mathrm{~h}$ was $375 \pm 110 \mathrm{pg} / \mathrm{ml}$. Infection with active HRV-14 increased this to $750 \pm 120 \mathrm{pg} / \mathrm{ml}$. By contrast, exposure to UV-inactivated virus resulted in the production of 

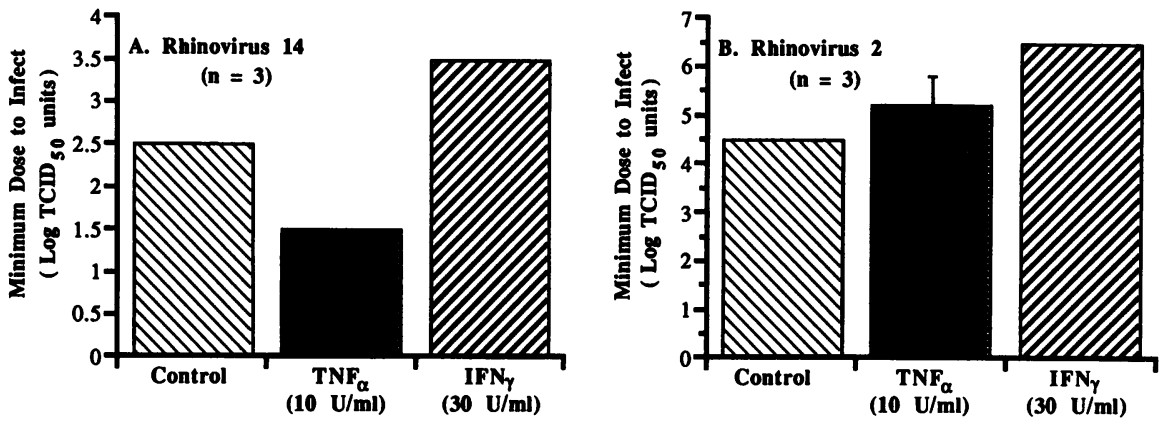

Figure 5. Comparison of the effects of $\mathrm{TNF}_{\alpha}$ and IFN ${ }_{\gamma}$ on the susceptibility of BEAS-2B cells to infection by HRV-14 and HRV-2. Data are expressed as means \pm SEM from three paired experiments. only $450 \pm 140 \mathrm{pg} / \mathrm{ml}$ of IL-8. Thus, UV inactivation significantly $(P<0.02)$ reduced virally induced cytokine production.

\section{Discussion}

Studies of the effects of rhinovirus infection on biochemical pathways of respiratory epithelial cells have been hampered by the lack of suitable in vitro culture systems. Because rhinovirus replicates only in higher primates (27), such studies mandate the use of human tissues. Previous attempts at in vitro systems have used polyp explants (28) or monolayer cultures derived from outgrowths of tissue fragments (29), but these cultures contain other cell types, most notably fibroblasts, making it difficult to delineate which biochemical events are directly attributable to viral infection of the epithelium. We now report the development, for the first time, of a culture system in which
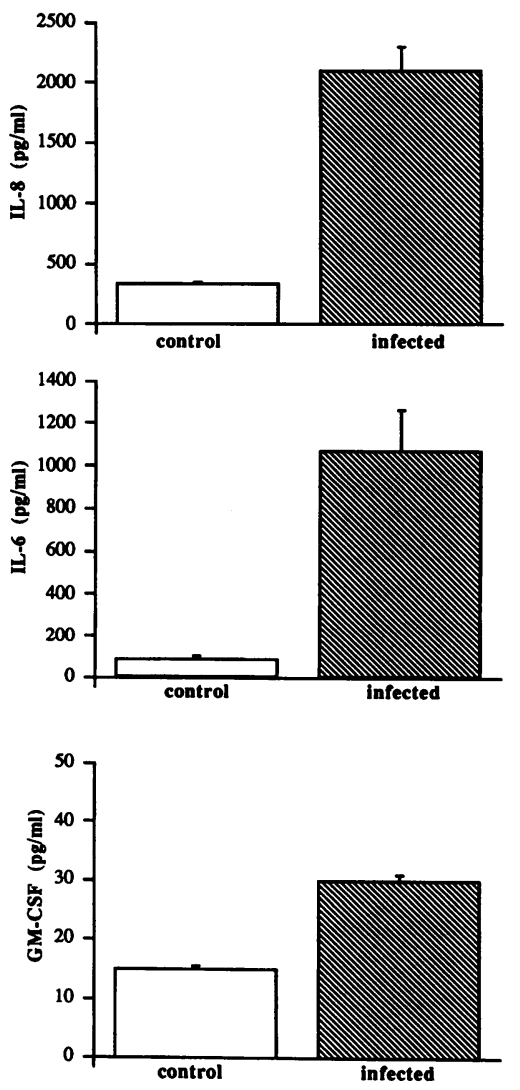

Figure 6. Levels of cytokines in supernatants collected $24 \mathrm{~h}$ after viral exposure from HRV-14 infected and uninfected BEAS-2B cells. Data are presented as means \pm SEM $(n=3)$. Note the differing ordinate scales. a pure population of human respiratory epithelial cells can be routinely infected with rhinovirus.

Viral infection of BEAS-2B cells, and proof of subsequent viral replication, was confirmed by several approaches: by demonstration of increased viral shedding into the culture medium of infected cells with time, assessed by the cytopathic effects of this medium on HeLa cells, and by showing that the cytopathic effects of BEAS-2B cell lysates also increased with time after infection. These studies implied that an equilibrium state between viral replication and shedding was reached by $\sim 24 \mathrm{~h}$ after infection, since the viral content of cell lysates remained almost constant at later time periods, even though viral titers during the second and third 24-h periods after infection remained comparable with those seen at $24 \mathrm{~h}$. The final method used to demonstrate viral replication relied on PCR of viral RNA after reverse transcription into DNA. Experimental conditions were established clearly demonstrating that viral RNA increased during the first $24 \mathrm{~h}$ after infection, as indicated by a pronounced band on PCR compared with the absence of any signal immediately after infection. The lack of any PCR signal immediately after infection, together with the inability to detect virus using the HeLa assay in either the supernatants or lysates of infected cells until 8-12 h after post infection, implies that very little virus is initally taken up during the infection process. This low efficiency of infection is consistent with studies performed using HeLa cells where the viral particle to infectious unit ratio was found to be as high as 800:1 (30).

The specificity of the infection process for BEAS-2B cells by HRV-14 was confirmed by demonstrating that infection could be blocked using a homotypic neutralizing antibody but not by an antibody to an unrelated serotype, HRV-2. Similarly, monoclonal antisera directed against the functional binding site of ICAM-1, the major rhinovirus receptor, could also block infection by HRV-14. In all of these experiments, however, it was necessary to restrict exposure times of cells to the virus to $15 \mathrm{~min}$. At longer incubation times (e.g., $1 \mathrm{~h}$ ), inhibition became less consistent, presumably because of the high affinity of the virus for its receptor and of the requirement for very few viral particles to enter the cell to induce infection.

Infection of BEAS-2B cells with HRV-14 was found to occur most easily when subconfluent monolayers were exposed to virus. The reasons for this are unclear. It is tempting to speculate that it may involve the relative distribution of ICAM1 on the luminal and basolateral surfaces of cells as they become confluent, but this seems unlikely because the BEAS-2B cell is relatively undifferentiated and does not form electrically tight junctions in culture. Moreover, confluent monolayers can still 

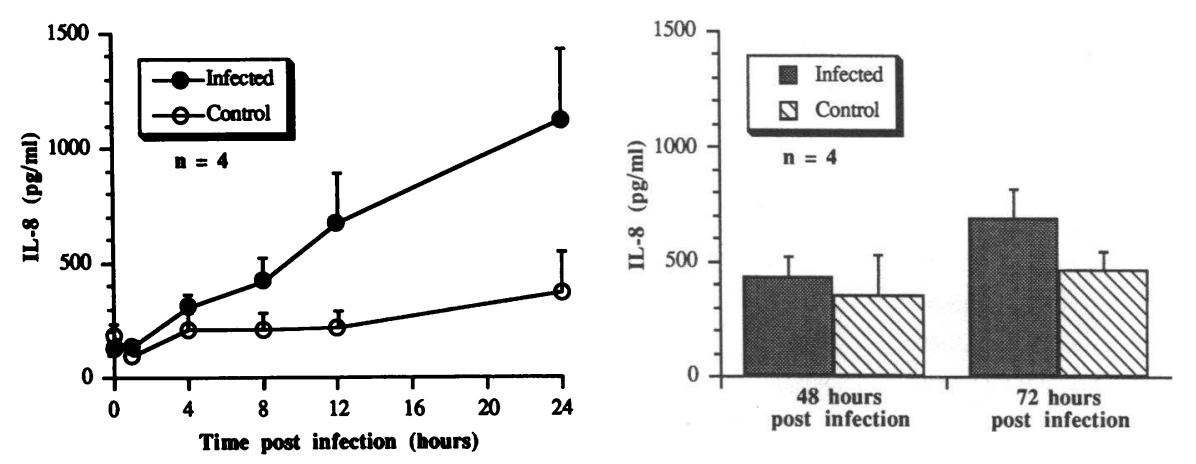

Figure 7. Time course of IL-8 production after viral infection. Data are expressed as means $\pm \operatorname{SEM}(n=4)$ and are from the same experiments used to monitor viral titers in Fig. 1. Control data are those from uninfected cells at the same time points.

routinely be infected, even though 10 -fold higher concentrations of virus are required (not shown). Regardless of the degree of confluence of monolayers at infection, rhinovirus infection did not affect cell growth rate. Moreover, a consistent observation is that rhinovirus infection is not cytotoxic for BEAS-2B cells, in that cell viability was routinely $>95 \%$ even at $6 \mathrm{~d}$ after infection. This is consistent not only with the observed lack of epithelial damage after rhinovirus infection in vitro (14) but also with prior studies using outgrowth monolayers in which cytopathic effects were noted on fibroblasts in the outgrowth populations but not on the epithelial cells (29). The lack of cytotoxicity in our model facilitates studies of virally induced biochemical changes in these cells, since the possibility that any such changes are occurring as a result of cell death can be ruled out.

It is known that cytokines can be generated by numerous cell types within the airways in response to a variety of stimuli and conditions. It has been shown that exposure of epithelial cells to cytokines such as TNF $\alpha$ and IFN $\gamma$ can upregulate the expression of ICAM-1 on these cells $(22,23)$. Moreover, in HeLa cells, upregulation of ICAM-1 by these cytokines is associated with inceased binding of major group rhinoviruses (31). On the other hand, interferons are effective prophylactic agents in preventing rhinovirus infections in vivo (32). To assess the effects of cytokines on the susceptibility of BEAS-2B cells to viral infection, we chose to monitor the lowest dose of virus capable of causing infection. This was considered preferable to monitoring viral titers at a fixed time after infection with a single dose of virus, since the latter parameter would be more susceptible to artifacts associated with changes in cell growth rates in response to cytokines. It was clear that TNF $\alpha$ increases susceptibility to infection with HRV-14, consistent with its ability to increase the expression of ICAM-1. The role of ICAM1 was confirmed in subsequent experiments in which it was

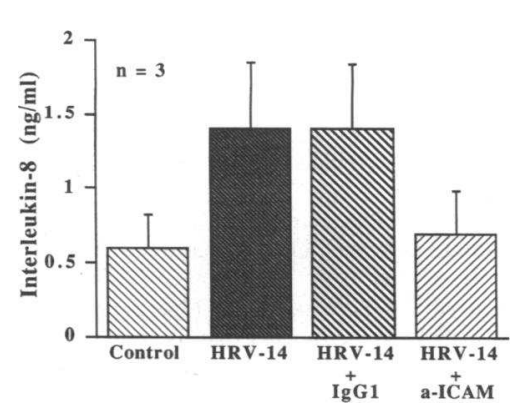

Figure 8. Preincubation of BEAS-2B cells with a monoclonal antibody $(84 \mathrm{H} 10)$ to the functional domain of ICAM1 , but not with a classmatched irrelevant antibody $\left(\operatorname{IgG}_{1}\right)$, inhibits virally induced IL-8 production. Data are expressed as means \pm SEM $(n=3)$. shown that TNF $\alpha$ had no effect on susceptibility to infection with HRV-2, a minor group rhinovirus that does not use ICAM1 as its receptor. In contrast, both IFN $\gamma$ (which also increases ICAM-1 expression) and IFN $\alpha$ (which does not alter ICAM1 expression) reduced the susceptibility of BEAS-2B cells to infection. Interestingly, when TNF $\alpha$ and IFN $\gamma$ were tested in combination, the antiviral effects of IFN $\gamma$ predominated. At this point, the predominant pathways triggered by IFN $\gamma$ in BEAS-2B cells to reduce susceptibility to infection are unknown, but IFN $\gamma$ can regulate replication of other viruses by several mechanisms in various cell types, including induction of indoleamine 2,3-dioxygenase (33), induction of $2^{\prime}, 5^{\prime}$-oligoadenylate synthetase (34), and induction of nitric oxide synthase (35). Whatever the mechanisms involved, these data are consistent with the hypothesis that the relative levels of cytokines within the airway may play a role in helping to explain the variations in susceptibility of individuals to infection.

In recent years, it has become apparent that the respiratory epithelial cell plays a much more active role in regulating airway inflammation than was appreciated previously, providing support for our hypothesis that stimulation of biochemical pathways in infected epithelial cells could induce a series of events that contribute to the pathogenesis of rhinovirus infections. It is also clear from the current studies that rhinovirus infection can stimulate epithelial cell cytokine production. That the increase in cytokine production was due to viral infection and not to a contaminant, such as a cytokine, in the viral stocks was confirmed by demonstrating that the increase in cytokine production could be inhibited by blockade of infection with antibodies to ICAM-1 or by inactivation of the virus with UV light. The enhanced production of IL-8 within $24 \mathrm{~h}$ after infection is in good agreement with previous studies demonstrating that infection of epithelial cells with influenza (36) or respiratory syncytial virus (RSV) (37) also stimulates IL-8 production in this time frame, before the onset of demonstrable cytotoxic effects. In the case of RSV infection, however, IL-8 production was not maximal, and IL-6 and GM-CSF production were not observed, until $96 \mathrm{~h}$ after infection, during the RSV replicative phase. In the current studies with rhinovirus, increased IL-8 production was also correlated with viral replication during the first $24 \mathrm{~h}$, and both IL-6 and GM-CSF could be detected within this time frame. In contrast to RSV, however, $\mathrm{IL}-8$ production tended to decrease at subsequent time points, despite the presence of continued viral replication. This is of interest given that the symptomatic phase of rhinovirus infections usually resolves within 5-6 d after infection, even though viral shedding can still be detected several days later (38). 
The cytokines produced from epithelial cells in response to viral stimulation have biological properties that are of interest with respect to the pathogenesis of colds. IL-8 is a potent chemoattractant for, and activator of, neutrophils (39) and also has chemotactic activity for lymphocytes (40), the two predominant cell types in the nasal mucosa during rhinovirus infections (14, 18 ). IL-6 can not only induce B cell differentiation and antibody production but is also capable of stimulating $\mathrm{T}$ cell activation (41). Finally, GM-CSF can prime both neutrophils and eosinophils for enhanced activation to chemical stimuli (42), and inhalation of aerosolized GM-CSF induced infiltration of activated macrophages and neutrophils in nonhuman primates (43). The capacity of rhinovirus to induce the production of all three of these epithelial cytokines is also of interest from the perspective of viral exacerbations of asthma, since increased epithelial expression of IL-8, IL-6, and GM-CSF has been reported in asthmatics (44).

In summary, we developed a model system in which a pure human respiratory epithelial cell line can be routinely infected with rhinovirus. Susceptibility to viral infection can be modified by preexposure of the cells to selected cytokines. Moreover, infection of epithelial cells with rhinovirus induces biochemical changes in the infected cells, as evidenced by the increased production of cytokines that could play a role in the recruitment and activation of inflammatory cells into the airway of infected individuals. Although it must be acknowledged that the BEAS2B is a transformed cell line and is not representative of normal airway epithelium in vivo, this cell type shares many properties in common with normal epithelial cells. This model system provides a valuable tool, therefore, for studying rhinovirus infection of epithelial cells and should yield useful insights into the early events associated with the pathogenesis of rhinovirus infections.

\section{Acknowledgments}

We thank Dr. Bruce Bochner and Dr. Dong-Chull Choi for assistance with flow cytometry experiments and neutrophil adhesion assays, respectively.

This work was supported in part by grants from the National Institutes of Health (HL-47120), the Procter and Gamble Company, the American Heart Association, and the Council for Tobacco Research.

\section{References}

1. Gwaltney, J. M., J. O. Hendley, G. Simon, and W. S. Jordan, Jr. 1966. Rhinovirus infection in an industrialized population. I. The occurrence of illness N. Engl. J. Med. 275:1261-1268.

2. Pattemore, P. K., S. L. Johnston, and P. G. Bardin. 1992. Viruses as precipitants of asthma symptoms. I. Epidemiology. Clin. Exp. Allergy. 22:325336.

3. Minor, T. E., E. C. Dick, J. W. Baker, J. J. Ouellette, M. Cohen, and C. E. Reed. 1976. Rhinovirus and influenza type $A$ infections as precipitants of asthma. Am. Rev. Respir. Dis. 113:149-153.

4. Lambert, H. P., and H. Stern. 1972. Infective factors in exacerbations of bronchitis and asthma. Br. Med. J. 3:323-327.

5. McHardy, V. U., J. M. Inglis, M. A. Calder, J. W. Crofton, I. Gregg, D. A Ryland, P. Taylor, M. Chadwick, D. Coombs, and R. W. Riddell. 1980. A study of infective and other factors in exacerbations of chronic bronchitis. Br. J. Dis. Chest. 74:228-238.

6. Turner, B. W., W. S. Cail, J. O. Hendley, F. G. Hayden, W. J. Doyle, J. V. Sorrentino, and J. M. Gwaltney, Jr. 1992. Physiologic abnormalities of the paranasal sinuses during experimental rhinovirus colds. J. Allergy Clin. Immunol. 90:474-478.

7. Gwaltney, J. M., Jr., C. D. Phillips, R. D. Miller, and D. K. Riker. 1994. Computed tomographic study of the common cold. N. Engl. J. Med. 330:25-30.
8. Arola, M., T. Ziegler, H. Puhakka, O. P. Lehtonen, and O. Ruuskanen. 1990. Rhinovirus in otitis media with effusion. Ann. Otol. Rhinol. \& Laryngol. 99:451-453.

9. Greve, J. M., G. Davis, A. M. Meyer, C. P. Forte, S. C. Yost, C. W. Marlor, M. E. Kamarck, and A. McClelland. 1989. The major human rhinovirus receptor is ICAM-1. Cell. 56:839-847.

10. Staunton, D. E., V. J. Merluzzi, R. Rothlein, R. Barton, S. D. Marlin, and T. A. Springer. 1989. A cell adhesion molecule, ICAM-1, is the major surface receptor for rhinoviruses. Cell. 56:849-853.

11. Albelda, S. M. 1991. Endothelial and epithelial cell adhesion molecules. Am. J. Respir. Cell Mol. Biol. 4:195-203.

12. Turner, R. B., J. O. Hendley, and J. M. Gwaltney, Jr. 1982. Shedding of infected ciliated epithelial cells in rhinovirus colds. J. Infect. Dis. 145:849-853.

13. Bardin, P. G., S. L. Johnston, G. Sanderson, S. Robinson, M. A. Pickett, D. J. Frankael, and S. T. Holgate. 1994. Detection of rhinovirus infection of the nasal mucosa by oligonucleotide in situ hybridization. Am. J. Respir. Cell Mol. Biol. 10:207-213.

14. Winther, B., B. Farr, R. B. Turner, J. O. Hendley, J. M. Gwaltney, Jr., and N. Mygind. 1984. Histopathologic examination and enumeration of polymorphonuclear leukocytes in the nasal mucosa during experimental rhinovirus colds Acta Oto-laryngol. Suppl. 413:19-24.

5. Naclerio, R. M., D. Proud, L. M. Lichtenstein, A. Kagey-Sobotka, J. O. Hendley, J. Sorrentino, and J. M. Gwaltney. 1987. Kinins are generated during experimental rhinovirus colds. J. Infect. Dis. 157:133-142.

16. Proud, D., R. M. Naclerio, J. M. Gwaltney, and J. O. Hendley. 1990. Kinins are generated in nasal secretions during natural rhinovirus colds. J. Infect. Dis. 161:120-123.

17. Proud, D., J. M. Gwaltney, Jr., J. O. Hendley, C. A. Dinarello, S. Gillis, and R. P. Schleimer. 1994. Increased levels of interleukin-1 are detected in nasa secretions of volunteers during experimental rhinovirus colds. J. Infect. Dis. 169:1007-1013.

18. Levandowski, R. A., C. W. Weaver, and G. G. Jackson. 1988. Nasal secretion leukocyte populations determined by flow cytometry during acute rhinovirus infection. J. Med. Virol. 25:423-432.

19. Reddel, R. R., Y. Ke, B. I. Gerwin, M. G. McMenamin, J. F. Lechner, R. T Su, D. E. Brash, J.-B. Park, J. S. Rhim, and C. C. Harris. 1988. Transformation of human bronchial epithelial cells by infection with SV40 or adenovirus-12 SV40 hybrid virus, or transfection via strontium phosphate coprecipitation with a plasmid containing SV40 early region genes. Cancer Res. 48:1904-1909.

20. Proud, D., M. C. Subauste, and P. E. Ward. 1994. Glucocorticoids do not alter peptidase expression on a human bronchial epithelial cell line. Am. J. Respir. Cell Mol. Biol. 11:57-65.

21. Johnston, S. L., G. Sanderson, R. K. Pattemore, S. Smith, P. G. Bardin, C. B. Bruce, P. R. Lambden, D. A. J. Tyrrell, and S. T. Holgate. 1993. Use of polymerase chain reaction for diagnosis of picornavirus infection in subjects with and without respiratory symptoms. J. Clin. Microbiol. 31:111-117.

22. Bloemen, P. G. M., M. C. van den Tweel, P. A. J. Henricks, F. Engels, S. S. Wagenaar, A. A. J. J. L. Rutten, and F. P. Nijkamp. 1993. Expression and modulation of adhesion molecules on human bronchial epithelial cells. Am. J. Respir. Cell Mol. Biol. 9:586-593.

23. Subauste, M. C., B. S. Bochner, and D. Proud. 1993. Modulation of ICAM-1 expression on a human bronchial epithelial cell line (BEAS-2B) by cytokines. Am. Rev. Respir. Dis. 147:A435. (Abstr.)

24. Bochner, B. S., A. A. McKelvey, R. P. Schleimer, J. E. K. Hildreth, and D. W. MacGlashan, Jr. 1989. Flow cytometric methods for the analysis of human basophil surface antigens and viability. J. Immunol. Methods. 125:265-271.

25. Schleimer, R. P., and B. K. Rutledge. 1986. Cultured human vascular endothelial cells acquire adhesiveness for leukocytes following stimulation with interleukin-1, endotoxin, and tumor-promoting phorbol esters. J. Immunol. 136:649-654.

26. Hughes, J. H., M. Mitchell, and V. V. Hamparian. 1979. Rhinoviruses: kinetics of ultraviolet inactivation and effects of $U V$ and heat on immunogenicity. Arch. Virol. 61:313-319.

27. Gwaltney, J. M., Jr. 1984. Rhinovirus. In Viral Infections of Humans. Epidemiology and Control. 2nd ed. A. S. Evans, editor. Plenum Medical Book Company, New York. 491-517.

28. Hamory, B. H., J. O. Hendley, and J. M. Gwaltney, Jr. 1977. Rhinovirus growth in nasal polyp organ culture. Proc. Soc. Exp. Biol. Med. 155:577-582.

29. Winther, B., J. M. Gwaltney, and J. O. Hendley. 1990. Respiratory virus infection of monolayer cultures of human nasal epithelial cells. Am. Rev. Respir. Dis. 141:839-845.

30. Lee, W.-M., S. S. Monroe, and R. R. Rueckert. 1993. Role of maturation cleavage in infectivity of picornaviruses: activation of an infectosome. $J$. Virol. 67:2110-2122.

31. Tomassini, J. E., D. Graham, C. M. DeWitt, D. W. Lineberger, J. A. Rodkey, and R. J. Colonno. 1989. cDNA cloning reveals that the major group rhinovirus receptor on HeLa cells is intercellular adhesion molecule 1. Proc. Natl. Acad. Sci. USA. 86:4907-4911. 
32. Hayden, F. G., J. K. Albrecht, D. L. Kaiser, and J. M. Gwaltney, Jr. 1986 Prevention of natural colds by contact prophylaxis with intranasal $\alpha_{2}$-interferon. N. Engl. J. Med. 314:71-75.

33. Yoshida, R., J. Imanishi, T. Oku, T. Kishida, and O. Hayaishi. 1981 Induction of pulmonary indoleamine 2,3-dioxygenase by interferon. Proc. Natl. Acad. Sci. USA. 78:129-132.

34. Zilberstein, A., A. Kimchi, A. Schmidt, and M. Revel. 1978. Isolation of two interferon-induced translational inhibitors: a protein kinase and an oligoisoadenylate synthetase. Proc. Natl. Acad. Sci. USA. 75:4734-4738.

35. Karupiah, G., Q. Xie, R. M. L. Buller, C. Nathan, C. Duarte, and J. D. MacMicking. 1993. Inhibition of viral replication by interferon- $\gamma$-induced nitric oxide synthase. Science (Wash. DC). 261:1445-1448.

36. Choi, A. M. K., and D. B. Jacoby. 1992. Influenza virus A infection induces interleukin-8 gene expression in human airway epithelial cells. FEBS (Fed. Eur. Biochem. Soc.) Lett. 309:327-329.

37. Noah, T. L., and S. Becker. 1993. Respiratory syncytial virus-induced cytokine production by a human bronchial epithelial cell line. Am. J. Physiol. 265:L472-L478.

38. Winther, B., J. M. Gwaltney, Jr., N. Mygind, R. B. Turner, and J. O. Hendley. 1986. Sites of rhinovirus recovery after point inoculation of the upper airway. JAMA (J. Am. Med. Assoc.). 256:1763-1767.

39. Baggiolini, M., A. Walz, and S. L. Kunkel. 1989. Neutrophil-activating peptide-1/interleukin 8 , a novel cytokine that activates neutrophils. J. Clin. Invest. 84:1045-1049.

40. Larson, C. G., A. O. Anderson, E. Appella, J. J. Oppenheim, and K. Matsushima. 1989. The neutrophil-activating protein (NAP-1) is also chemotactic for T lymphocytes. Science (Wash. DC). 243:1464-1466.

41. Akira, S., T. Hirano, T. Taga, and T. Kishimoto. 1990. Biology of multifunctional cytokines: IL 6 and related molecules (IL 1 and TNF). FASEB (Fed. Am. Soc. Exp. Biol.) J. 4:2860-2867.

42. Lopez, A. F., D. J. Williamson, J. R. Gamble, C. G. Begley, J. M. Harlan, S. J. Klebanoff, A. Waltersdorph, G. Wong, S. C. Clark, and M. A. Vadas. 1986. Recombinant human granulocyte-macrophage-colony stimulating factor stimulates in vitro mature human neutrophil and eosinophil function, surface receptor expression, and survival. J. Clin. Invest. 78:1220-1228.

43. Rose, R. M., L. Kobzik, K. Dushay, S. Wolfthal, M. Hondalus, M. Metzger, J. Stoudemire, J. D. Brain, M. Garnick, C. O'Donnell, and R. E. Donahue. 1992 The effect of aerosolized recombinant human granulocyte macrophage colony stimulating factor on lung leukocytes in nonhuman primates. Am. Rev. Respir. Dis. 146:1279-1286.

44. Marini, M., E. Vittori, J. Hollemborg, and S. Mattoli. 1992. Expression of the potent inflammatory cytokines, granulocyte-macrophage colony-stimulating factor and interleukin- 6 and interleukin-8 in bronchial epithelial cells of patients with asthma. J. Allergy Clin. Immunol. 82:1001-1009. 